\title{
EFFECT Of NATURAL AdDITIONS FROM MARJORAM AND PUMPKIN SEEDS ON THE RHEOLOGICAL AND SENSORY PROPERTIES Of WheAt FlOUR BREAD
}

\author{
By \\ Naglaa M.Shanshan ${ }^{\star}$ and Dina H.EL Bushuty ${ }^{\star}$ \\ *Home Economics Department, Faculty of Specific Education in Damietta, \\ Mansoura University, Egypt.
}

Research Gournal Specific Fducation

Faculty of Specific Education

Mansoura University

ISSUE NO. 23, PART II, OCT. 2011

مجلة بحوث التربية النوعية - جامعة المنصورة

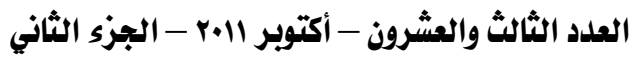




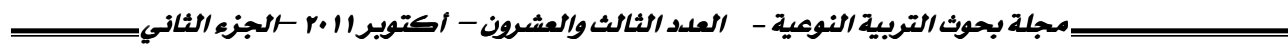 \\ EFFECT OF NATURAL ADDITIONS FROM MARJORAM AND PUMPKIN SEEDS ON THE RHEOLOGICAL AND SENSORY PROPERTIES OF WHEAT FLOUR BREAD

\author{
by \\ Naglaa M.Shanshan* and Dina H.EL Bushuty* \\ *Home Economics Department, Faculty of Specific Education in Damietta, \\ Mansoura University, Egypt.
}

\begin{abstract}
The present study aimed to examine the effect of adding Marjoram and Pumpkin seeds on sensory and rheological properties of wheat flour bread. For this purpose, Marjoram was added in replacement rates of 5\% and 10\%, as well as in the case of Pumpkin seeds flour (5\% and $10 \%$ replacement), they were added together by replacement rates 5\%. Then were compared to those mixtures with bread wheat flour $(100 \%$ wheat flour) to determine the effect of each on the chemical composition of bread, sensory and rheological properties of bread. The results showed that the additions have led to an increase in the content of the bread in protein, fat, fiber and ash, also led to decreased in carbohydrates. The results of farinograph and extinsograph showed that the addition of Marjoram has led to decreased in the rate of water absorption and extensibility, on the other hand it led to increase the stability, dough development time, degree of softening, elasticity and the proportional number, whereas adding Pumpkin seeds led to decrease in the rate of water absorption, extensibility and increasing the degree of softening, elasticity and the proportional number, while adding the blend of the two together has led to decrease in the rate of water absorption, extensibility, stability, and increasing in the degree of softening, elasticity and the proportional number. For the sensory properties did not show significant differences between the bread wheat flour, bread flour mixed with Pumpkin seeds by 5\% in the taste, color, tenderness and overall acceptability. While significant differences appeared when 0.05 level of significance between each of the bread wheat flour, bread flour mixture Marjoram rates of 5\% and $10 \%$ in all sensory properties that have been studied as well as in the case of bread made from mixture both. Based on the above, the current study recommends adding pumpkin seed flour to bread wheat flour by $5 \%$.
\end{abstract}

Key words: Marjoram, Pumpkin seeds, Wheat flour bread, Sensory properties, Rheological properties. 


\title{
EFFECT OF NATURAL ADDITIONS FROM MARJORAM AND PUMPKIN SEEDS ON THE RHEOLOGICAL AND SENSORY PROPERTIES OF WHEAT FLOUR BREAD
}

\author{
by \\ Naglaa M.Shanshan* and Dina H.EL Bushuty*
}

*Home Economics Department, Faculty of Specific Education in Damietta, Mansoura University, Egypt.

\section{Introduction}

Today's consumers are conscious of their diet, and many prefer eating healthy foods. Bread seems to be a good vehicle in this respect if part of the wheat flour were to be replaced with non wheat flours (Basman et al., 2003).

Bread is one of the most important foods consumed all over the world (Mirsaeedghazi et al., 2008). Bread products are well accepted worldwide because of the low cost, ease of preparation, versatility, sensory attributes and nutritional properties(Fang, 2008). In Egypt wheat flour bread represents the main source of carbohydrate for most of the people $(\boldsymbol{E} \boldsymbol{L}$ Soukkary, 2001).

Nowadays, emphasis is on healthy bread with low glycemic index, more protein and will increase the dietary fiber intake, high resistant starch and decrease in calori and carbohydrates of baked goods(Seeean, 2008).

The pumpkin (Cucurbita moschata) is an annual dicotyledonous vegetable, belonging to the Cucurbitaceae family. It is used as a medicinal plant for prostate and bladder problems, and as an anthelmintic, galactogogue, and anti-emetic (Magdeleine et al, 2011).Some scientific literature highlights its importance as a source of $\alpha$ and $\beta$-carotene, vitamin $\mathrm{C}$, dietary fiber, minerals, and phenolic compounds. These nutrimental and bioctive components are very important in providing human health benefits(Valenzuela et al., 2011).

Pumpkin seeds (PS), which used to be discarded after the preprocessing of the fruit, have been, nowadays, subjected to industrial processing and have been commonly commercialized as a savory appetizer. The application of these seeds can be considered a good alternative for the nutritional enrichment of food products(Gorgonio et al., 2011). 
Pumpkin seeds, generally thrown away are otherwise, a rich source of oil and nutrients and could be consumed as food(Dhiman et al., 2009). Pumpkin seeds have a high nutritional value, provides good quality oil, and excellent source of protein(Mahasneh and El-Oqlah, 1999).

The seed of pumpkin has pharmacological activities such as antidiabetic, antifungal, antibacterial and antiinflammation activities, and antioxidant effects (Atuonwu and Akobundu, 2010; Abd El-Aziz and Abd Kalek, 2011). Pumpkin seeds are considered an alternative treatment for stage I and II benign prostatic hyperplasia and for irritable bladder(Winkler et al., 2005). The seeds are mildly diuretic and vermifuge (Pandya and Rao, 2010).

Marjoram (or Sweet Marjoram) is a herbaceous, perennial plant native to Cyprus and the Eastern Mediterranean countries(Novak et al., 2000; Verma, 2010; Verma et al., 2010).

Sweet marjoram (Origanum majorana L. Syn. Majorana hortensis), a member of the Lamiaceae family(Sellamia, et al., 2009) . Marjoram was grown in Egypt under the conditions of organic and traditional agriculture (Edris et al., 2003).

Marjoram is one of the most familiar kitchen herbs. It is cultivated for use of its aromatic leaves for flavouring and other culinary purposes(Ahmed et al., 2009). Marjoram is used in many, marjoram is added to soups, salad dressings, sauces for stewed meats (mainly mutton) and stuffing's.(Kumar et al., 2011).

The medicinal effects of marjoram are gastrointestinal tract stimulant, tonic, carminative, diaphoretic, hypoglycemic, diuretic as well as antibacterial (Ahmed et al., 2009). It has strong antioxidant activity, mainly because of its high content of phenolic acids and flavonoids, which is useful in health supplements and food preservation(Banchio et al., 2008; Sellamia , et al., 2009). Traditionally, the plant has been used as a folk remedy against asthma, indigestion, headache and rheumatism (Sellamia, et al., 2009). Marjoram is used for cramps, depression, dizziness, , migraine, nervous headaches, paroxysmal coughs ( Yazdanparast and Shahriyary, 2008).

Rheological properties of dough are very important indices for product development in terms of product quality and process efficiency(Sivam et al., 2010), and it is very important to understand 
mechanical properties of the dough and control finished products(Mirsaeedghazi et al, 2008).

There are many techniques for studying the rheological properties of dough. In about 1930, one of the first special instruments was designed for physical testing of wheat flour dough, the so-called Brabender Farinograph(Mirsaeedghazi et al, 2008). The Brabender Farinograph is the most popular dough rheology instrument and its results are relatively easy to interpret (Doerry, 1995) .

Parameters usually applied in the baking industry water absorption or percentage of water required to yield dough consistency of $500 \mathrm{BU}$ (Brabender Units)(wang et al., 2002), dough Stability is given by the time from when the Farinograph trace touches the 500 BU line up to the break time, the time required for dough development or time necessary to reach 500 BU of dough consistency (Ammar et al., 2011), and elasticity (band width of the curve at the maximum consistency) (wang et al., 2002).

This paper report on the effect of marjoram and pumpkin seed flour on some sensory and rheological properties of wheat flour bread.

\section{Materials and Methods}

\section{Ingredients:}

Wheat flour ( $72 \%$ extraction), Pumpkin (Cucurbita moschata) seeds and Marjoram ( Majorana hortensis) were obtained from the local market.

\section{Preparing of Pumpkin seeds flour:}

The seeds were cleaned by hand to remove broken seeds and foreign materials, then were crushed in household mill, as soon as, The marjoram was crushed in household mill, then was sifted.

\section{Preparing of bread:}

- Wheat flour bread (control) was prepared from $100 \%$ wheat flour extraction $72 \%, 8 \%$ dry yeast, $5 \%$ sugar, $1 \%$ salt with the addition of water for kneading.

- Pumpkin seeds bread:

1. Pumpkin seeds bread by $5 \%$ Pumpkin seeds flour (5\%PSF) : was prepared from $95 \%$ wheat flour extraction $72 \%, 5 \%$ pumpkin seeds 
flour, $8 \%$ dry yeast, $5 \%$ sugar, $1 \%$ salt with the addition of water for kneading.

2. Pumpkin seeds bread by $10 \%$ Pumpkin seeds flour (10\% PSF) : was prepared from $90 \%$ wheat flour extraction $72 \%, 10 \%$ pumpkin seeds flour, $8 \%$ dry yeast, $5 \%$ sugar, $1 \%$ salt with the addition of water for kneading.

- Marjoram bread:

1. Marjoram bread by $5 \%$ marjoram flour $(5 \% \mathrm{MF})$ : was prepared from $95 \%$ wheat flour extraction $72 \%, 5 \%$ marjoram flour, $8 \%$ dry yeast, $5 \%$ sugar, $1 \%$ salt with the addition of water for kneading.

2. Marjoram bread by $10 \%$ marjoram flour (10\% MF): was prepared from $90 \%$ wheat flour extraction $72 \%, 10 \%$ marjoram flour, $8 \%$ dry yeast, $5 \%$ sugar, $1 \%$ salt with the addition of water for kneading.

- Marjoram and Pumpkin seeds bread was prepared from 95\% wheat flour extraction $72 \%, 2.5 \%$ pumpkin seeds flour, $2.5 \%$ marjoram flour, $8 \%$ dry yeast, $5 \%$ sugar, $1 \%$ salt with the addition of water for kneading.

\section{Chemical analyses:}

Protein, fat, ash and fiber content were determined according to the A.O.A.C (2000), while total carbohydrate were calculated by the difference. Total caloric content was determined by calculation. According to Lawrence (1965) Using the following equation : total caloric (Kcal/100g) = (protein content $\mathrm{x} 4)+($ fat content $\times 9)+($ carbohydrate content $\mathrm{x} 4)$

\section{Sensory properties:}

Sensory property for bread was evaluated by 10 trained panelists according to Watts et al., (1989).

\section{Rheological properties:}

The farinograph and extinsograph tests were carried out in Food Technology Research Institute, Agriculture Research Center, Giza, Egypt. 


\section{Statistical analysis :}

All the obtained data were statistically analyzed by SPSS computer soft ware. The calculated occurred by analysis of variance ANOVA and follow up test LSD by SPSS ver.11 according to Artimage and Berry (1987).

\section{Results and Discussion}

\section{Effect of treatments on chemical composition of produced bread:}

Present data in table (1) showed the effect of treatments on chemical composition of produced bread. Results cleared that there were significant ( $\mathrm{p}<0.05)$ differences between wheat flour bread (control) and produced bread of 5\% Marjoram flour, 10\% Marjoram flour, 10\% Pumpkin seeds flour and 5\%( Marjoram flour+ Pumpkin seeds flour) in protein , fat, fiber, ash, and carbohydrates. Treatments led to increasing in the content of bread from protein , fat, fiber, ash, and decreased in carbohydrates. Also appeared significant $(\mathrm{p}<0.05)$ differences between wheat flour bread and produced bread of 5\% Pumpkin seeds flour in protein, fat, fiber, and carbohydrates, 5\% Pumpkin seeds flour led to increasing in the content of produced bread from protein , fat, fiber, and decreased in carbohydrates.

In this respect EL-Soukkary, (2001) demonstrated that, Pumpkin seeds products as a good source of protein and nutrients for fortification of baked products, especially bread. Also, the Pumpkin seeds flour is used as a protein supplement in bread(Dhiman et al., 2009). 
Table ( 1): Effect of treatments on chemical composition of produced bread $/ 100 \mathrm{~g}$.

\begin{tabular}{|c|c|c|c|c|c|c|}
\hline Composition & 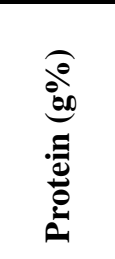 & 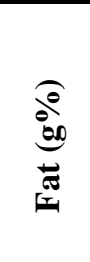 & 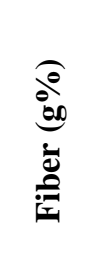 & $\begin{array}{l}\widehat{0} \\
\frac{0}{00} \\
\frac{1}{4}\end{array}$ & 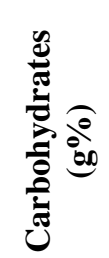 & 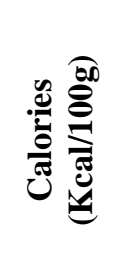 \\
\hline Control & 11.41e & $2.10 \mathrm{e}$ & $2.31 \mathrm{e}$ & $1.70 f$ & $74.19 \mathrm{a}$ & 361.30 \\
\hline $5 \% \mathrm{MF}$ & $11.52 \mathrm{f}$ & $2.28 \mathrm{f}$ & 3.06b & $2.29 \mathrm{~b}$ & $71.66 \mathrm{~b}$ & 353.24 \\
\hline MF $10 \%$ & 11.64d & $2.57 d$ & 3.81a & $2.89 a$ & $70.02 f$ & 349.77 \\
\hline $5 \%$ PSF & $12.06 b$ & $4.06 \mathrm{~b}$ & $2.49 \mathrm{f}$ & $1.72 \mathrm{f}$ & $71.08 d$ & 369.10 \\
\hline $10 \%$ PSF & 12.72a & $6.00 \mathrm{a}$ & $2.67 d$ & 1.82d & $68.86 \mathrm{e}$ & 380.32 \\
\hline $5 \%(\mathrm{MF}+\mathrm{PSF})$ & $11.76 \mathrm{c}$ & $3.17 \mathrm{c}$ & $2.78 c$ & $2.01 c$ & $71.37 \mathrm{c}$ & 361.05 \\
\hline
\end{tabular}

- Control:100\% Wheat flour, MF: Marjoram flour, PSF: Pumpkin seeds flour.

- Different letters on same column represent statistically significant $(p<0.05)$ difference between means.

- means of three determinations.

\section{Effect of treatments on sensory evaluation of produced bread:}

Effect of treatments on sensory evaluation of produced bread are presented in table (2). Results cleared that there were significant $(\mathrm{p}<0.05)$ differences between wheat flour bread (control) and produced bread of 5\% Marjoram flour , 10\% Marjoram flour, and 5\%( Marjoram flour+ Pumpkin seeds flour) in all sensory evaluation ( aroma, taste, color, tenderness, and overall acceptability, also these results showed that no significant differences between wheat flour bread (control) and produced bread of 5\% Pumpkin seeds flour in taste, color, tenderness, and overall acceptability. Similarly, did not show significant differences between wheat flour bread (control) and produced bread of 10\% Pumpkin seeds flour in color.

According to Sivam et al, .(2010) the addition of different types of fibers may affect sensory attributes of baked products. Also Sangnark and Noomhorm (2004) reported that sensory evaluation all decreased as each of dietary fiber increased. A significant problem with dietary fiber addition in bread-type products is poor textural quality(Gomez et al., 2003). 
Table ( 2 ): Effect of treatments on sensory evaluation of produced bread.

\begin{tabular}{|c|c|c|c|c|c|}
\hline Treatments & 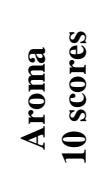 & 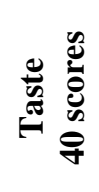 & 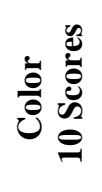 & 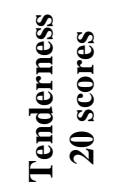 & 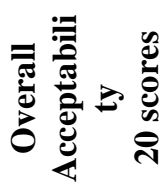 \\
\hline Control & $9.3 \mathrm{a}$ & $39.2 \mathrm{a}$ & $9.1 \mathrm{ab}$ & $19.3 a$ & $19.6 a$ \\
\hline $5 \%$ MF & $7.0 \mathrm{~cd}$ & $30.8 c$ & $6.5 \mathrm{c}$ & $16.3 \mathrm{c}$ & 15.5d \\
\hline $10 \% \mathrm{MF}$ & $5.7 f$ & $21.8 f$ & $2.7 f$ & 13.8d & $3.3 f$ \\
\hline $5 \%$ PSF & $8.3 \mathrm{~b}$ & 37.4a & $9.2 \mathrm{a}$ & 17.9ab & 18.9ab \\
\hline $10 \%$ PSF & 7.6bc & 33.5b & $8.4 b$ & $17.8 b$ & $16.6 \mathrm{c}$ \\
\hline$(\mathrm{MF}+\mathrm{PSF}) \mathbf{5 \%}$ & $6.2 \mathrm{df}$ & 34.4b & $7.0 \mathrm{c}$ & 13.9d & $15.6 \mathrm{~cd}$ \\
\hline
\end{tabular}

- Control:100\% Wheat flour, MF: Marjoram flour, PSF: Pumpkin seeds flour.

- Different letters on same column represent statistically significant $(p<0.05)$ difference between means.

\section{Effect of treatments on rheological properties:}

Table (3), and figure 1 to 3 showed the effect of treatments on farinograph parameters, the results revealed that the addition of Marjoram flour has led to decreased in the rate of water absorption, and increasing in dough development time, stability, and degree of softening (figure1). Also , the results revealed that the addition of Pumpkin seeds flour has led to decreased in the rate of water absorption, and increasing in degree of softening(figure2). While the results showed that the addition of 5\% from Mixture Marjoram flour and Pumpkin seeds flour has led to decreased in the rate of water absorption, and stability, and increasing in degree of softening(figure 3 ).

Present data in table (3) and figure 4 to 6 showed the Effect of treatments on extensograph parameters. Results cleared that the addition of Marjoram flour(figure 4), Pumpkin seeds flour (figure 5), and Mixture Marjoram flour and Pumpkin seeds flour(figure 6) has led to decreased in extensibility, and increasing in elasticity, and the proportional number.

In this respect Rabie et al., (2009) demonstrated that, the rheological parameters evaluated on farinograph and extensograph indicated very clear effect of fat type and ratio, decrease in water absorption, and extensibility recorded as the fat ratio raised. 
العدد الثالث والعشرون - أكتوير |l ـr - الجزي الثاني-

| مجلة بحوث التربية النوعية - مجية

Table (3): Effect of treatments on rheological properties.

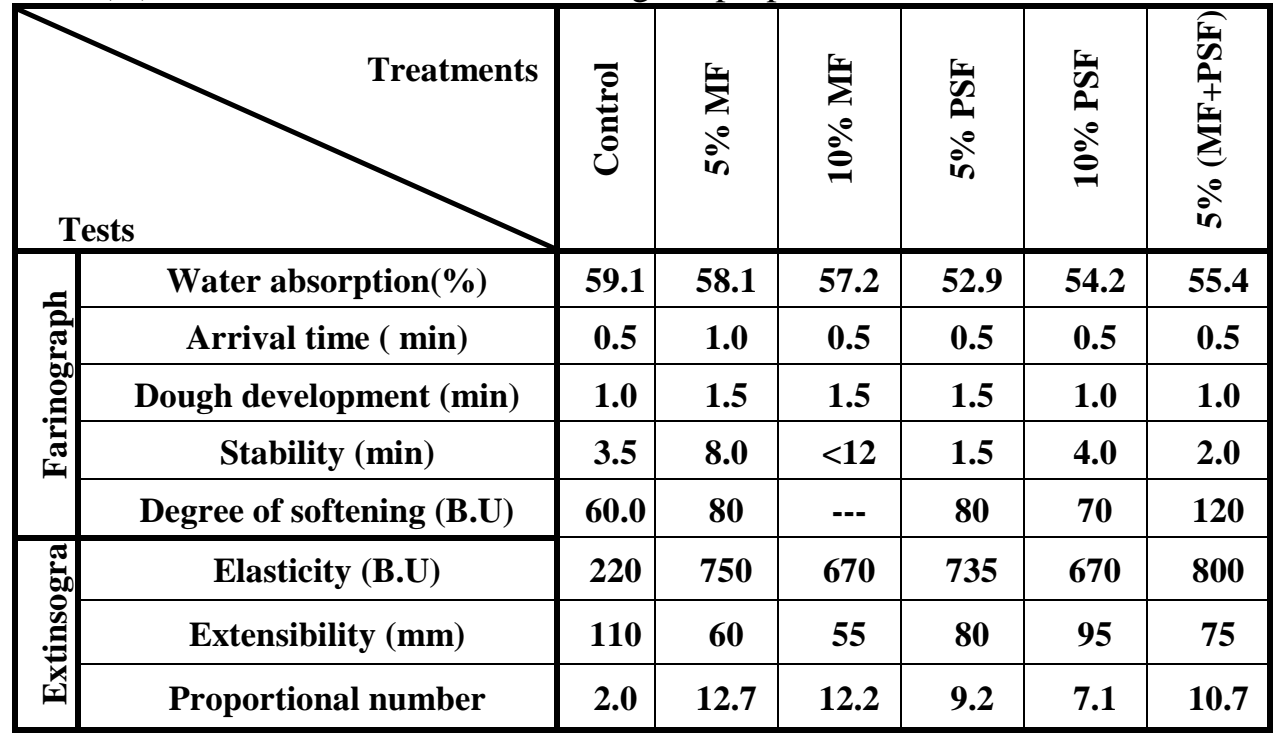

- Control:100\% Wheat flour, MF: Marjoram flour, PSF: Pumpkin seeds flour.

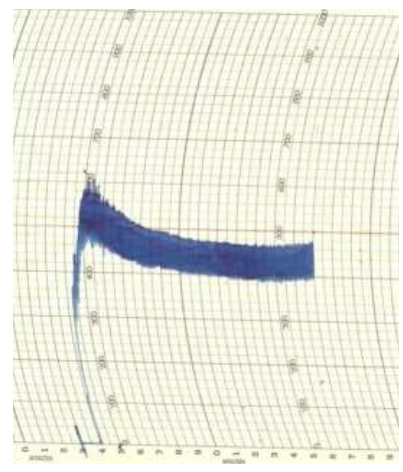

Control

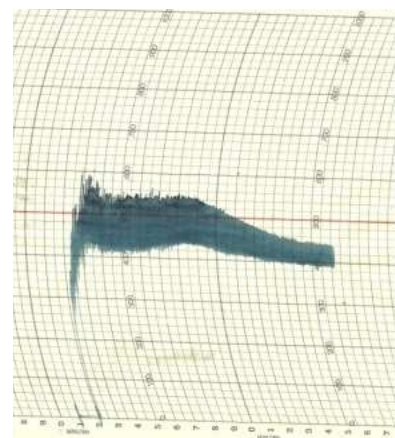

$5 \% \mathrm{MF}$

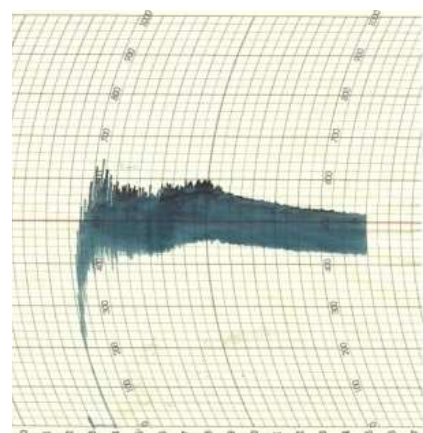

$10 \% \mathrm{MF}$

Fig 1: Effect of addition $(5 \%, 10 \%)$ Marjoram flour on farinograph parameters. 

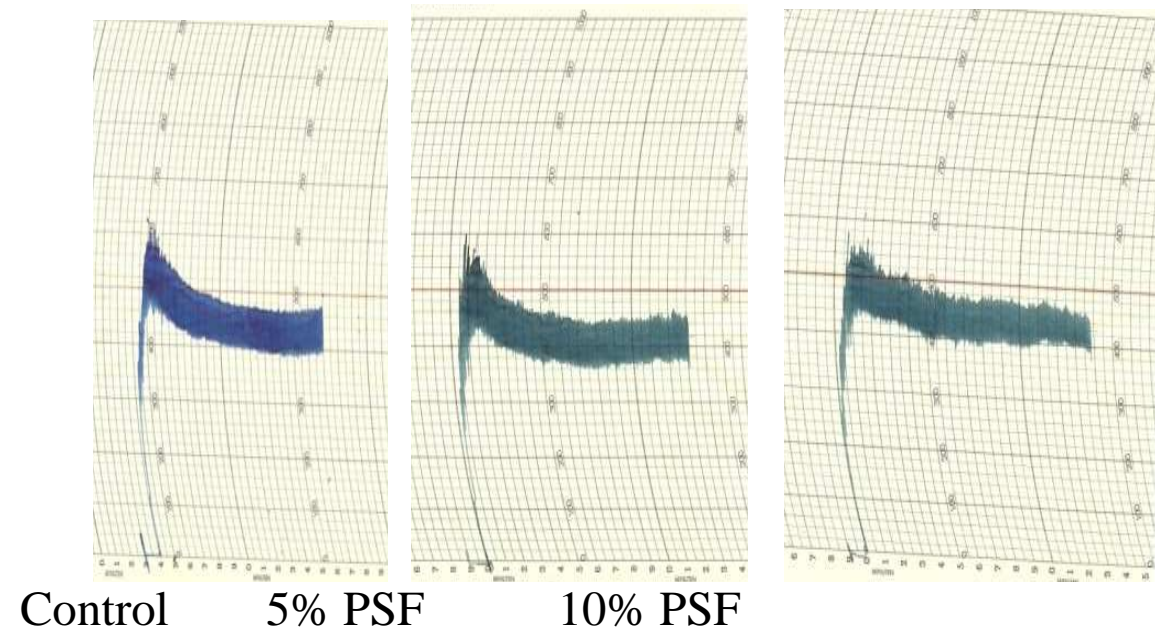

Control 5\% PSF

Fig 2: Effect of addition( $5 \%, 10 \%)$ Pumpkin seeds flour on farinograph parameters.
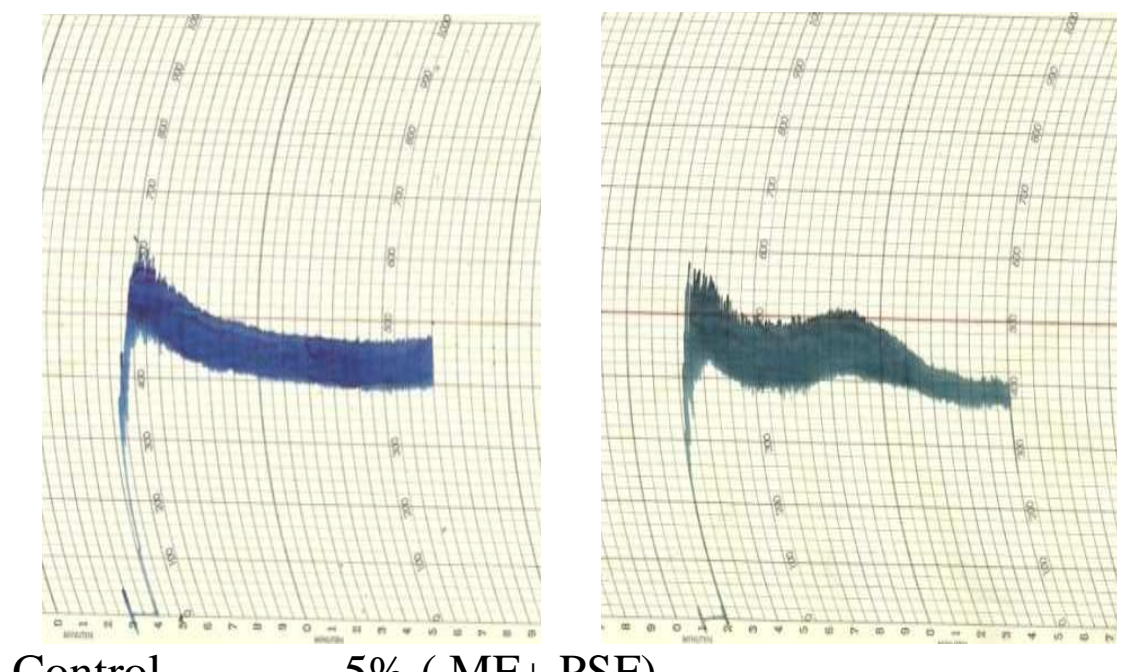

Control

$5 \%$ ( MF+ PSF)

Fig 3: Effect of addition 5\% ( Marjoram flour + Pumpkin seeds flour) on farinograph parameters 


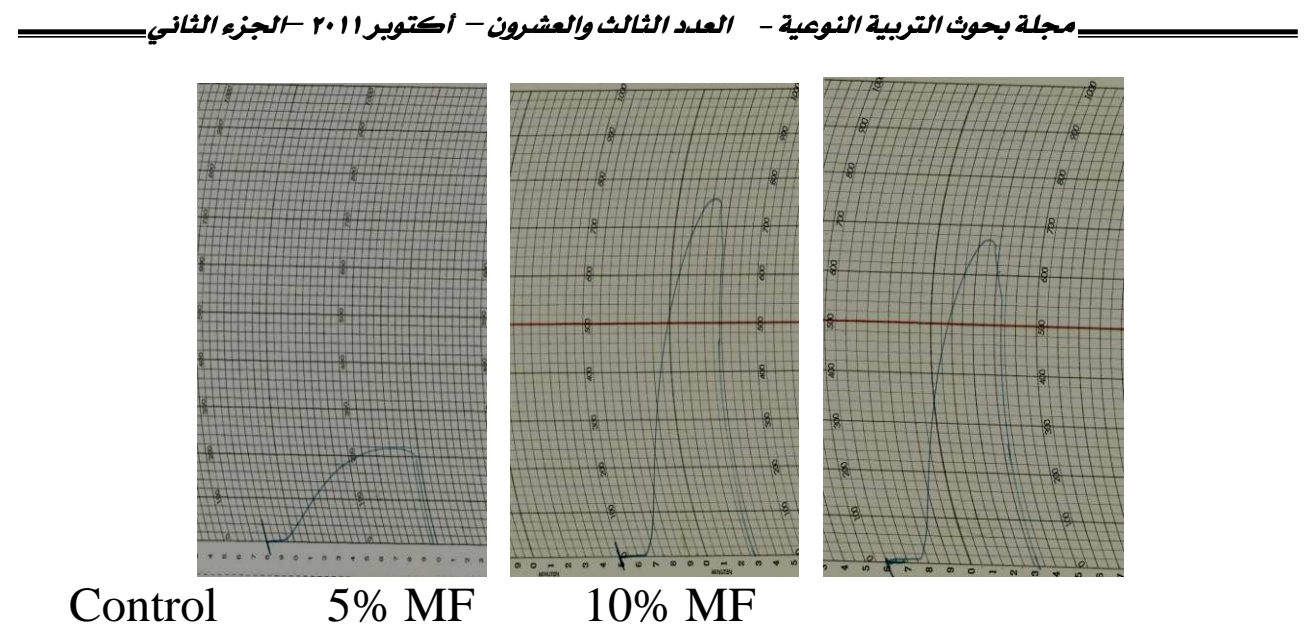

Fig 4: Effect of addition ( 5\%, 10\%) Marjoram flour on extensograph parameters.
Control
$5 \%$ PSF
$10 \%$ PSF
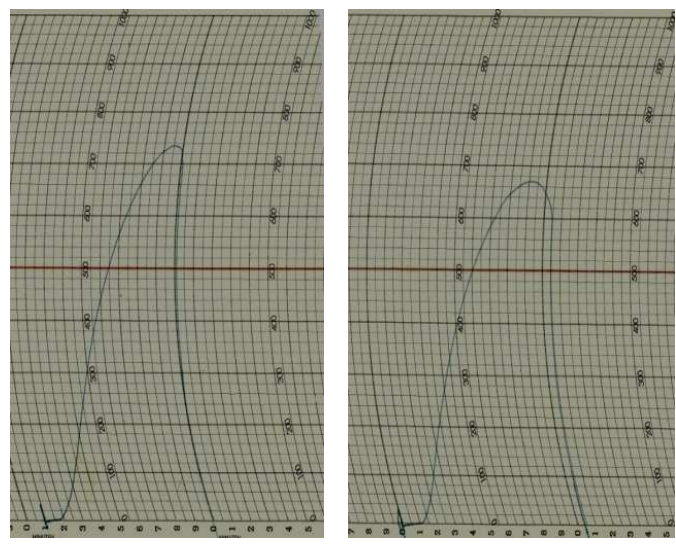

Fig 5: Effect of addition( 5\%, 10\%) Pumpkin seeds flour on extensograph parameters.
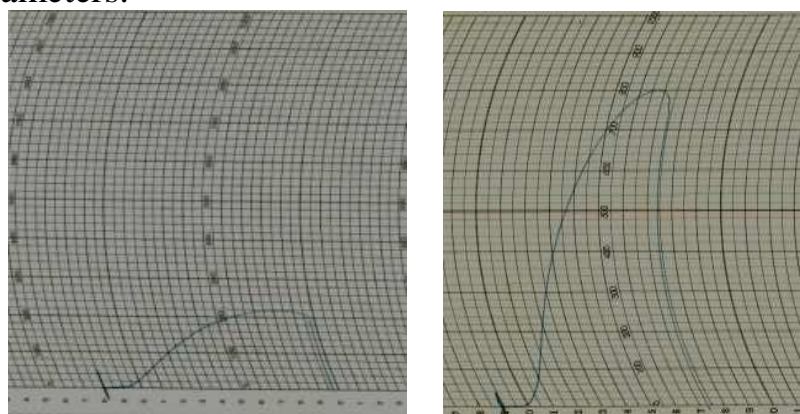

Control

$5 \%$ ( MF+ PSF)

Fig 6: Effect of addition 5\% ( Marjoram flour + Pumpkin seeds flour) on extensograph parameters 


\section{References}

- Abd El-Aziz; A.B. and Abd El- Kalek, H.H. (2011): Antimicrobial proteins and oil seeds from pumpkin (Cucurbita moschata). Nature and Science , 9(3):105-119.

- Ahmed, L.A.; Ramadan, R.S. and Mohamed, R.A. (2009): Biochemical and Histopathological Studies on the Water Extracts of Marjoram and Chicory Herbs and Their Mixture In Obese Rats. Pakistan Journal of Nutrition , 8 (10): 1581-1587.

- Ammar, A.S.; Salem, S.A. and Badr, F.H. (2011): Rheological Properties of Wheat Flour Dough as Affected by Addition of Whey and Soy Proteins. Pakistan Journal of Nutrition , 10 (4): 302-306.

-A.O.A.C. (2000): Association of Official Agricultural Chemists. Official Method of Analysis. $17^{\text {th }}$ Ed. Vol. 11. Washington U.S. A.

-Artimage, G.Y. and Berry, W.G. (1987): Statistical Methods $7^{\text {th }}$ Ed. Ames, Iowa Stata University Press, 39-63.

-Atuonwu, A.C. and Akobundu , E.N.T. (2010): Nutritional and Sensory Quality of Cookies Supplemented with Defatted Pumpkin (Cucurbita pepo) Seed Flour. Pakistan Journal of Nutrition, 9 (7): 672-677.

- Banchio, E. ; Bogino, P.C. ; Zygadlo, j . and Giordanoa, W.(2008): Plant growth promoting rhizobacteria improve growth and essential oil yield in Origanum majorana L. Biochemical Systematics and Ecology, 36(10):766-771.

- Basman, A.; Koksel, H. and P.K.W.NG(2003): Utilization of Transglutaminase to Increase the Level of Barley and Soy Flour Incorporation in Wheat Flour Breads. Journal of food science, 68(8):2453-2460.

- Dhiman, A.K.; Sharma, K.D. and Attri, S.(2009): Functional constituents and processing of pumpkin: A review. Journal of Food Science and Technology, 46(5):411-417.

- Doerry, W.T.( 1995): Bread Making Technology - An Introduction to Bread Making in North America. Kansas: American Institute of Baking.

- Edris , A.E.; Shalaby, A. and Fadel, H.M.(2003): Effect of organic agriculture practices on the volatile aroma components of some essential oil plants growing in Egypt II: sweet Marjoram (Origanum marjorana L.) essential oil. Flavour and Fragrance Journal , 18(4):345- 351.

- EL-Soukkary, F.A.H.( 2001): Evaluation of pumpkin seed products for bread fortification. Plant Foods for Human Nutrition, 56: 365-384

- Fang, S. (2008): Physico-chemical and Organoleptic Evaluations of Wheat Bread Substituted With Different Percentage of Pumpkin Flour (Cucurbita moschata). Universiti Sains Malaysia. 
-Gomez, M.; Ronda, F.; Blanco, C.A.;Caballero, P.A. and Apesteguia, A. (2003): Effect of dietary fibre on dough rheology and bread quality. European Food Research and Technology, 216: 51-56.

- Gorgonio, C.M.S; Pumar, M. and Mothe, C.G.(2011): Macrocospic and physiochemical characterization of a sugarless and gluten-free cake enriched with fibers made from pumpkin seed (Cucurbita maxima, L.) flour and cornstarch. Ciênc. Tecnol. Aliment., Campinas, 31(1): 109118 .

- Kumar , B.S.; Kumar, R.M.; Tamizhmani, T.; Rahiman, F.OM. and Niyas, M.K.(2011): Majorana Hortensis (M.): A Review Update. An International Journal of Pharmaceutical Sciences, 1152-1167.

-Lawrence, R.D. (1965): The diabetic life. J. and A. Churchill, LTD. London.

- Magdeleine , C.M. ; Mahieu , M . and Archimede , H.(2011): Chapter 110 Pumpkin (Cucurbita moschata Duchesne ex Poir.) Seeds as an Anthelmintic Agent?. Nuts and Seeds in Health and Disease Prevention, 933-939.

- Mahasneh, A.M. and El-Oqlah, A.A. (1999): Antimicrobial activity of extracts of herbal plants used in the traditional medicine of Jordan. Journal of Ethno pharmacology, 64: 271-276.

- Mirsaeedghazi, H.; Emam-Djomeh, Z. and Mousavi, S.M.A. (2008): Rheometric measurement of dough rheological characteristics and factors affecting It. Int. J. Agri. Biol., 10(1): 112-119.

-Novak, J.; Bitsch, C.; Langbehn, J.; Pank, F.; Skoula, M; Gotsiou, Y.and Franz, C.M.(2000): Ratios of cis- and trans-Sabinene Hydrate in Origanum majorana L. and Origanum microphyllum (Bentham) Vogel. Biochemical Systematics and Ecology , 28:697-704.

- Pandya, J.B .and Rao, T. V.R.(2010): Analysis of Certain Biochemical Changes Associated with Growth and Ripening of Pumpkin Fruit in Relation to its Seed Development. Journal of Pure and Applied Sciences, 18: 34 - 39.

- Rabie, M.M.; Hassan, A.M.; Abou Raia, M.A. and EL Adle, O.(2009): Effect of Fatt Matters on Dough Rheological Properties and Sensory Evaluation of Bakery Products. Journal of Agricultural Sciences, Mansoura University, 34:2911-2921.

- Sangnark, A. and Noomhorm, A.(2004): Effect of dietary fiber from sugarcane bagasse and sucrose ester on dough and bread properties. LebensmittelWissenschaft und-Technologie, 37(7):697-704.

- Sellamia, I.H. ; Maamourib, E. ; Chaheda, T. ; Wannesa, W.A.; Kchouka, M.E. and Marzouka, B.(2009): Effect of growth stage on the content and composition of the essential oil and phenolic fraction of sweet marjoram (Origanum majorana L.). Industrial Crops and Products, 30(3): 395- 402 . 
-Sivam, A.S.; Waterhouse, D.S.; Quek, S.Y. and Perera, C.O.(2010): Properties of Bread Dough with Added Fiber Polysaccharides and Phenolic Antioxidants: A Review. J Food Sci, 75(8): 163-174.

- Valenzuela, N.G.; Junior, M.R.M ; Morales, J.J.Z. and Infante, J.A.G.(2011): Physicochemical, technological properties, and healthbenefits of Cucurbita moschata Duchense vs. Cehualca: A Review. Food Research International, 44(9):2587-259.

- Verma, R.S. (2010): Aroma Profile of Majorana hortensis as Influenced by Harvesting Height in Northern India. Chem. Bull. "POLITEHNICA" Univ. (Timisoara), 55(69):9-11.

- Verma, R.S.; Sashidhara, K.V.; yadav , A. and Naqvi, A.A.(2010): Essential oil composition of Majorana hortensis (Moench) from subtropical India. Acta Pharmaceutica Sciencia, 52:19-22.

- Wang, J.; Rosell, C.M. and Barber, C.B.(2002): Effect of the addition of different fibres on wheat dough performance and bread quality. Food Chemistry, $79: 221-226$.

-Watts, B.M.; Ylimaki, L.E.; Jeffery L.E. and Elias, L.G. (1989): Basic Sensory Methods for Food Evaluation. IDRC, Canada.

-Winkler. C ; Wirleitner . B ; Schroecksnadel , K ; Schennach, H .and Fuchs, D. (2005): Extracts of pumpkin seeds suppress stimulated peripheral blood mononuclear cells in vitro. American Journal of Immunology, 1 (1): 6-11.

- Yazdanparast, R. and Shahriyarya, L.(2008): Comparative effects of Artemisia dracunculus, Satureja hortensis and Origanum majorana on inhibition of blood platelet adhesion, aggregation and secretion. Vascular Pharmacology, 48(1):32-37. 


\section{تأثير الإضافات الطبيـية هن البردقوش وبذور القرع العسلي علي الخواص الصسية والريولوجية لخبرز دقيق القمه هد/نجلاء مسعد شنشن هد/دينا حامد البشوتى}

هرقم الاقتصداد المنزلي - كلية التربية النوعية بلدياط- جامعة المنصورة- مصر.

\section{unil|}

تهدف الدراسة الحالية إلي دراسـة تأثير إضافة البردقوش وبذور القرع العسلي علي الخواص الحسيـة والريولوجيـة لخبـز دقيـق القهـح • ولهـذا الغـرض تم إضـافة مطحسون البردقـوث ودقيـق بـذور القرع العسلي ه و • ٪ استبدال علي الترتيب، كما تم إضافة خليط مـن الاثنين معـاً بنسبـة استبدال

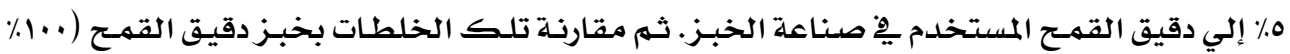
دقيق قهـح ) وذلك لمعرفـة مـدي تأثر كل مـن تركيـب الخبـزوخواصسه الحسية والريولوجيـة بتلـك الإضـافات. ولقد أظهرت النتائج أن الإضـافات قد أدت إلي زيادة ـِّه محتوي الخبـز مـن البروتين والدهن

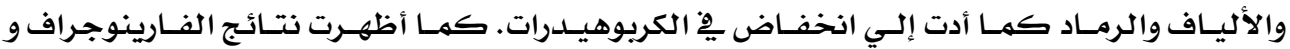
الاكستنسوجراف أن إضـافة مطحون البردقوش قد أدي إلي انخفاض ِِْ نسبة الامتصاص والمطاطيـة

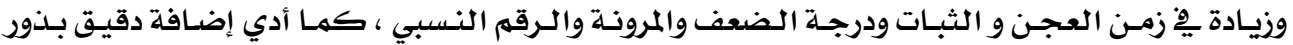

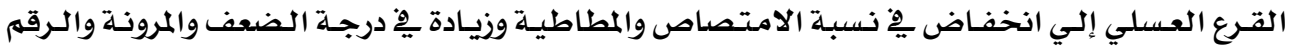
النسبي ، أما إضافة خليط الاثنين معاً فقد أدي إلي انخفاض يخّ نسبة الامتصاص والمطاطيـة والثبـات وزيادة ِِّ درجـة الضعف والمرونة والرقم النسبي • وبالنسبـة للخـواص الحسية لم تظهر فروق ذات دلالـة معنوية بين كل من خبز دقيق القمـح والخبز المخلوط بدقيق بذور القـرع العسلي بنسبة ه٪ ـِ الطعهم واللون والقوام والقبول العام • بينما ظهرت فروق ذات دلالة معنوية عند مستوى معنوية ه . · بـين كل

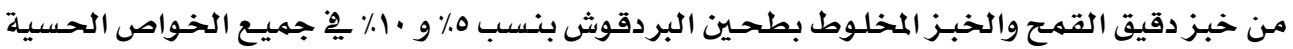

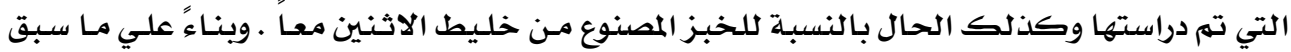

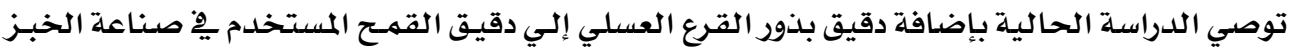

